INTIQAD: JURNAL AGAMA DAN PENDIDIKAN ISLAM

ISSN 1979-9950 (print) || ISSN 2598-0033 (online), http://jurnal.umsu.ac.id/index.php/intiqad DOI: 10.30596/intiqad.v13i2.8059

Vol. 13, No. 2 (December 2021)

\title{
Islam Negeri Selangor Tahun 2003 Mengenai Pendaftaran Poligami di Mahkamah Rendah Syariah Hulu Langat Selangor (Studi Kasus Mahkamah Rendah Syariah Negeri Selangor, Malaysia)
}

\author{
Muhammad Syukri Albani Nasution'*, Hasbullah Dja'far², \\ Muhammad Syazwan Bin Basri ${ }^{3}$ \\ Universitas Islam Negeri Sumatera Utara*1,2,3 \\ *1email:msyukrialbani@gmail.com
}

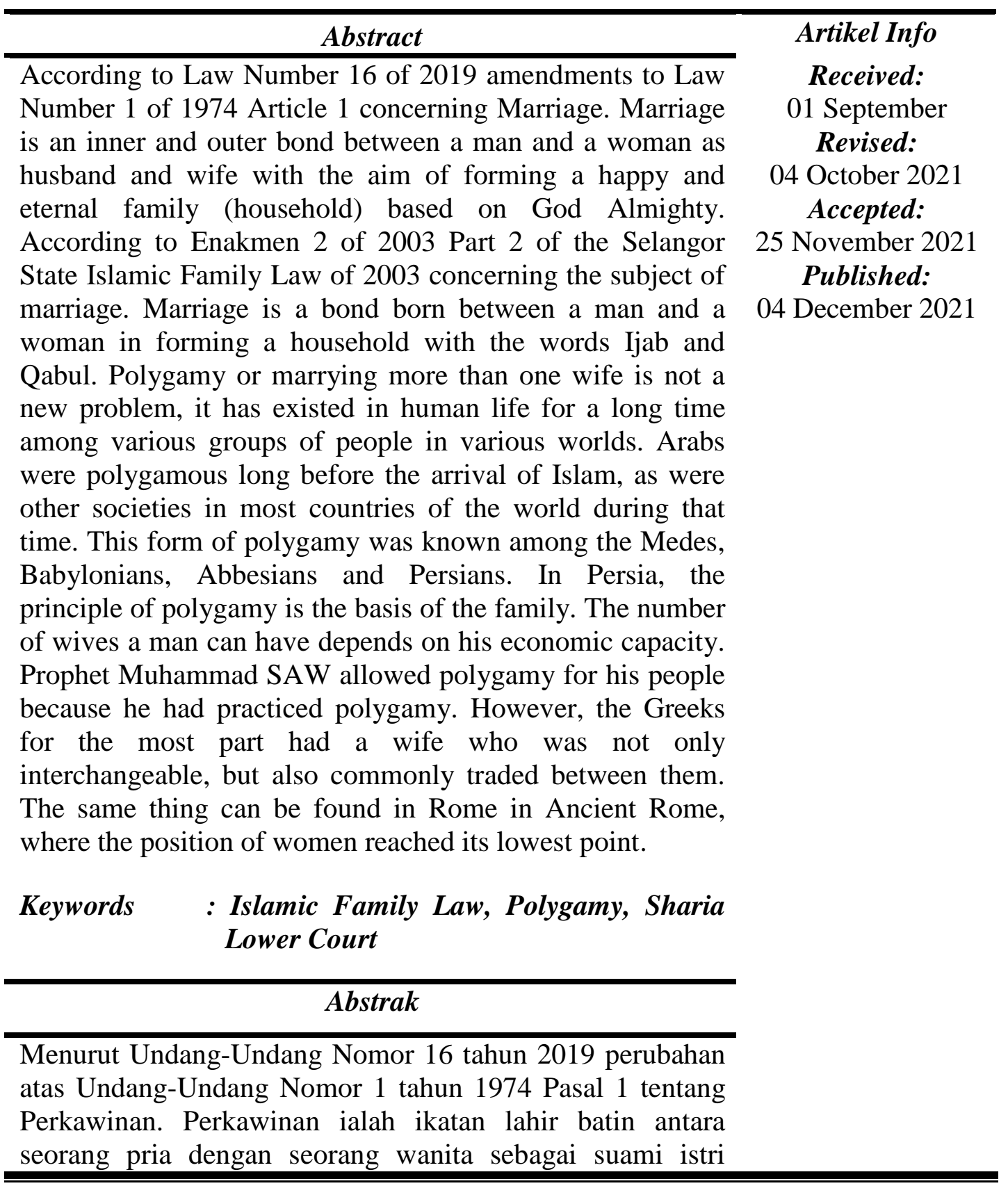


dengan tujuan membentuk keluarga (rumah tangga) yang bahagia dan kekal berdasarkan ketuhanan Yang Maha Esa. Menurut Enakmen 2 Tahun 2003 Bagian 2 Hukum Keluarga Islam Negeri Selangor Tahun 2003 tentang pokok perkawinan. Perkawinan ialah satu ikatan yang lahir antara seorang lelaki dan perempuan di dalam membentuk rumah tangga dengan lafaz Ijab dan Qabul. Poligami atau menikahi lebih dari satu orang istri bukan merupakan masalah baru, hal itu telah ada dalam kehidupan manusia sejak dulu di antara berbagai kelompok masyarakat di berbagai dunia. Orang-orang Arab telah berpoligami bahkan jauh sebelum kedatangan Islam, demikian pula masyarakat lain di sebagian besar negara di dunia selama masa itu. Bentuk poligami ini telah dikenal di antara orang-orang Medes, Babilonia, Abbesinia dan Persia. Di Persia, prinsip poligami merupakan basis keluarga. Jumlah isteri yang dapat dimiliki seorang laki-laki bergantung pada kemampuan ekonominya. Nabi Muhammad SAW membolehkan poligami untuk masyarakatnya karena beliau telah mempraktikkan poligami tersebut. Namun, orang-orang Yunani sebagian besar mempunyai seorang istri yang bukan hanya dapat dipertukarkan, tetapi juga bisa diperjualbelikan secara lazim diantara mereka. Hal serupa bisa dijumpai di Romawi pada masa Romawi Kuno, dimana kedudukan wanita mencapai titik terendahnya

\section{Kata Kunci : Undang-Undang Keluarga Islam, Poligami, Mahkamah Rendah Syariah}

\section{A. Pendahuluan}

Menurut Undang-Undang Nomor Undang-Undang 16 tahun 2019 perubahan atas Undang-Undang 1 tahun 1974 Pasal 1 tentang Perkawinan. Perkawinan ialah ikatan lahir batin antara seorang pria dengan seorang wanita sebagai suami isteri dengan tujuan membentuk keluarga (rumah tangga) yang bahagia dan kekal berdasarkan ketuhanan Yang Maha Esa (UU Perkawinan No. 1, 1974).

Menurut Enakmen 2 Tahun 2003 Bagian 2 Hukum Keluarga Islam Negeri Selangor Tahun 2003 tentang pokok perkawinan. Perkawinan ialah satu ikatan yang lahir antara seorang lelaki dan perempuan di dalam membentuk rumah tangga dengan lafaz Ijab dan Qabul. 
Enakmen adalah suatu UndangUndang yang sah serta legal dan dibahas di dalam dewan undangan Negeri-negeri semenanjung dan daerah Sabah setelah kemerdekaan yang dibuat oleh masingmasing dan Enakmen tersebut disahkan oleh Dewan Undangan Negeri (DUN) di Semenanjung Malaysia. Dalam hal ini bertujuan agar setiap Undang-undang yang ada di setiap provinsi Malaysia disebut sebagai Enakmen.

Perkawinan dalam Islam pada dasarnya menganut asas monogami, karena asas tersebut yang lebih dapat menjamin terpenuhinya hak-hak istri (Ghazaly, 2003). Namun demikian, Islam membolehkan suami melakukan poligami disertai dengan syarat-syarat yang ketat yaitu kemampuan suami berlaku adil terhadap para istrinya, persyaratan adil dalam poligami menunjukkan bahwa pernikahan suami dengan lebih dari satu istri tidak hanya mengacu kepada kepentingan seksual tetapi disertai pula penghormatan kepada hak-hak istri (Tihami, Sahrani, 2014).

Poligami atau menikahi lebih dari satu orang istri bukan merupakan masalah baru, hal itu telah ada dalam kehidupan manusia sejak dulu di antara berbagai kelompok masyarakat di berbagai dunia (I Doi, 1996). Orangorang Arab telah berpoligami bahkan jauh sebelum kedatangan Islam, demikian pula masyarakat lain di sebagian besar negara di dunia selama masa itu. Bentuk poligami ini telah dikenal di antara orang-orang Medes, Babilonia, Abbesinia dan Persia. Di Persia, prinsip poligami merupakan basis keluarga. Jumlah isteri yang dapat dimiliki seorang laki-laki bergantung pada kemampuan ekonominya (I Doi, 1992). Nabi Muhammad SAW membolehkan poligami untuk masyarakatnya karena beliau telah mempraktikkan poligami tersebut. Namun, orang-orang Yunani sebagian besar mempunyai seorang istri yang bukan hanya dapat dipertukarkan, tetapi juga bisa diperjualbelikan secara lazim diantara mereka. Hal serupa bisa dijumpai di Romawi pada masa Romawi Kuno, dimana kedudukan wanita mencapai titik terendah-nya (al-Habsyi, $\mathrm{tt})$.

Islam memperbolehkan laki-laki melaksanakan poligami sebagai alternatif ataupun jalan keluar untuk mengatasi penyaluran kebutuhan biologis atau sebab-sebab lain yang mengganggu ketenangan batinnya agar 
INTIQAD: JURNAL AGAMA DAN PENDIDIKAN ISLAM

ISSN 1979-9950 (print) || ISSN 2598-0033 (online), http://jurnal.umsu.ac.id/index.php/intiqad DOI: 10.30596/intiqad.v13i2.8059

Vol. 13, No. 2 (December 2021) tidak sampai jatuh ke lembah perzinahan. Oleh sebab itu, tujuan poligami adalah menghindari agar suami tidak terjerumus ke jurang maksiat yang dilarang Islam dengan mencari jalan yang halal, yaitu boleh beristeri lagi (poligami) dengan syarat berlaku adil. Sebagaimana firman-Nya dalam Al Quran Surat An Nisa ayat 3:

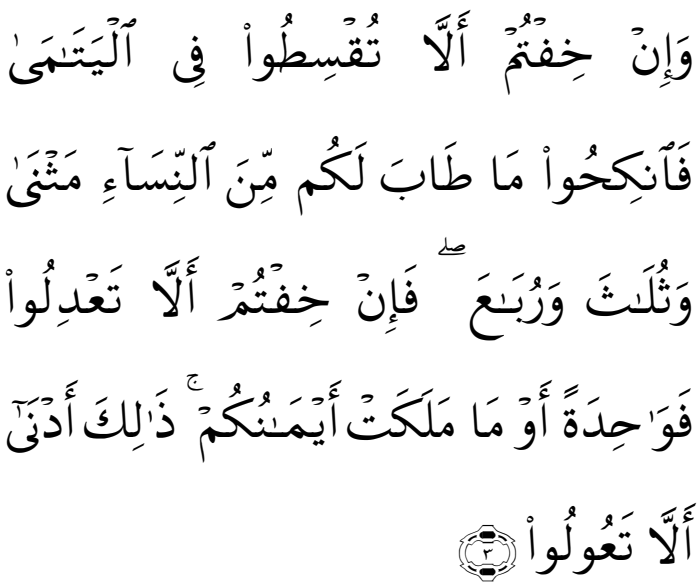

Artinya: Dan jika kamu takut tidak akan dapat berlaku adil terhadap (hak-hak) perempuan yang yatim (Apabila kamu mengawininya), maka nikahilah wanitawanita (lain) yang kamu senangi: dua, tiga atau empat. Kemudian jika kamu tidak dapat berlaku adil maka kawinilah seorang saja atau budak-budak yang kamu miliki. Yang demikian itu lebih dekat kepada tidak berbuat aniaya (Q.S. An-Nisa: 3).

Ayat di atas dapat dipahami bahwa seorang laki-laki boleh memiliki satu, dua, tiga atau bahkan empat istri, dengan syarat mampu berlaku adil jika tidak mampu maka cukup satu orang istri saja.
Berlaku adil yang dimaksud adalah dapat memenuhi kebutuhan-kebutuhan istri dan anak-anaknya yaitu dalam mempersiapkan seperti: pakaian, tempat tinggal, giliran mengunjungi, pemeliharaan dan pendidikan anak, dan agama mereka. Kemampuan berlaku adil merupakan syarat wajib dalam poligami yang menjadi kesepakatan ulama. Kemampuan berlaku adil tersebut dijadikan dasar seorang suami boleh melakukan poligami atau tidak (Izzat, 2004).

Oleh sebab itu, Poligami diatur di dalam Seksyen 23 bagian 2 Enakmen Keluarga Islam Negeri Selangor Tahun 2003 yaitu "Permohonan untuk kebenaran hendaklah dikemukakan kepada Mahkamah mengikut cara yang ditetapkan dan hendaklah disertai dengan suatu iqrar menyatakan alasanalasan mengapa perkawinan yang direncanakan itu dikatakan patut atau perlu, pendapatan pemohon pada masa itu, butir-butir komitmennya dan kewajiban tanggungan kewenangannya yang patut ditentukan, bilangan orang tanggungannya, termasuk orang yang akan menjadi tanggungannya bersama dengan perkawinan yang direncanakan itu, dan meskipun izin atau pandangan 
isteri atau isteri-isterinya telah diperoleh atau belum terhadap perkawinan yang direncanakan itu" (Enakmen 2 Tahun 2003). Masalah ini telah ditetapkan bahwa pasangan yang ingin melaksanakan poligami perlu mendaftarkan perkawinannya di Mahkamah seperti yang termaktub di dalam Seksyen 16 bagian 2 Enakmen Keluarga Islam Negeri Selangor Tahun 2003 yaitu "Apabila dikehendaki untuk mengakad-nikahkan sesuatu perkawinan dalam Negeri Selangor tiap-tiap satu pihak kepada perkawinan yang dicadangkan itu hendaklah memohon dalam borang yang ditetapkan untuk kebenaran perkawinan kepada Pendaftar bagi kariah masjid di mana pihak perempuan itu bermastautin" (Enakmen 2 Tahun 2003).

Berkaitan dengan permohonan untuk kebenaran menikah dan Seksyen 17 bagian 2 Enakmen Keluarga Islam Negeri Selangor Tahun 2003 berkaitan “Tertakluk kepada seksyen 18, (Enakmen 2 Tahun 2003). Pendaftar, apabila berpuas hati tentang kebenaran perkara-perkara yang disebut dalam permohonan itu, tentang sahnya perkawinan yang direncanakan itu. Dan jika pihak lelaki itu sudah menikah, bahwa kebenaran yang dikehendaki oleh seksyen 23 telah diberi, hendaklah, pada bila-bila masa selepas permohonan itu dan setelah dibayar fi yang ditetapkan, mengeluarkan kepada pemohon kebenarannya untuk berkawin dalam borang yang ditetapkan dengan keluarnya kebenaran perkawinan oleh Mahkamah Rendah Syariah Negeri Selangor.

Ketetapan ini dilakukan karena pihak mahkamah perlu melihat dari setiap sudut kemampuan suami yang ingin melaksanakan poligami. Hal ini perlu diperhatikan agar tidak terjadi ketidakadilan dan ketidakmampuan setelah melakukan poligami nanti karena hal ini akan menyebabkan perpecahan rumah tangga jika tidak diperhatikan sebelum terjadinya pernikahan.

Bunyi pasal di atas dapat dipahami bahwa poligami dibolehkan apabila telah memenuhi ketentuan yang telah diatur dan harus mendapatkan izin dari mahkamah dengan mengemukakan alasan-alasannya.

Kenyataan dalam masyarakat Daerah Hulu Langat. Negeri Selangor mayoritas perkawinan poligami itu dilakukan tanpa pengetahuan isteri mereka dan berlaku tanpa kebenaran 
pihak mahkamah. Sehingga perkawinan tersebut tidaklah mempunyai kekuatan hukum. Praktek poligami yang terjadi di Daerah Hulu Langat, Negeri Selangor. Padahal dalam Enakmen 16 UndangUndang Keluarga Islam Negeri Selangor Tahun 2003 telah ditetapkan setiap perkawinan yang dijalankan perlu memohon kebenaran perkawinan atau poligami di Mahkamah Rendah Negeri Selangor Namun realitas yang terjadi di masyarakat Hulu Langat, Negeri Selangor ada beberapa orang yang melakukan poligami di luar izin isteriisteri dan Mahkamah yang mengakibatkan kesulitan dalam rumah tangga tersebut setelah perkara itu diketahui oleh pihak Mahkamah. Dengan kata lain, poligami dilaksanakan tanpa peduli dengan syariat dan UndangUndang yang telah mengaturnya, seakan mereka lupa bahwa poligami pada saatnya juga akan dipertanggungjawabkan di hadapan Allah SWT. Jika pahami bersama tujuan poligami adalah untuk membentuk kekuatan Islam seperti ketika zaman Rasulullah berpoligami adalah untuk menyelamatkan agama dan membantu kaum Muslimat juga (Sunarto, 2014).
Hal ini telah terjadi di Daerah Hulu Langat, Negeri Selangor. Dimana ada beberapa kasus diantaranya adalah tertuduh Tuan Abdul Fattah Bin Dato' Kamaruddin yang pada 27-01-2016 di wilayah, Songhkla Thailand dituduh berpoligami tanpa persetujuan Mahkamah, dengan seorang perempuan bernama Elli Yuliana (No. PPT: AR 564728) berlawanan dengan Seksyen 23 Enakmen Undang-Undang Keluarga Islam (Negeri Selangor) 2003. Maka dengan itu, beliau telah melakukan kesalahan menurut seksyen 124 Enakmen Undang-Undang Keluarga Islam (Negeri Selangor) 2003 dan hendaklah dihukum denda tidak melebihi seribu ringgit atau penjara tidak lebih dari enam bulan atau keduanya, di bawah seksyen dan Enakmen yang sama. Ini adalah Kasus kesalahan matrimoni berkaitan dengan berpoligami tanpa persetujuan Mahkamah di bawah seksyen 124 EUUKIS 2003.

Keduannya, tertuduh Mohd Nurul Azhar Bin Mohd Tohar yang pada 13 Mac 2018 jam lebih kurang 01.00 petang di Wilayah Pattani, Thailand dituduh berpoligami tanpa persetujuan mahkamah dengan seorang perempuan bernama Rs (NO.K/P: xxxxx) yang 
INTIQAD: JURNAL AGAMA DAN PENDIDIKAN ISLAM

ISSN 1979-9950 (print) || ISSN 2598-0033 (online), http://jurnal.umsu.ac.id/index.php/intiqad

DOI: 10.30596/intiqad.v13i2.8059

Vol. 13, No. 2 (December 2021)

berlawanan dengan seksyen 23 Enakmen Undang-Undang Keluarga Islam (Negeri Selangor) 2003 dan hendaklah dihukum denda tidak melebihi seribu ringgit atau penjara enam bulan atau kedua duanya di bawah Seksyen dan Enakmen yang sama. Tertuduh juga disabitkan di bawah seksyen 134,40 (2) Berpoligami tanpa kebenaran pendaftar dan Bersubahat.

Tertuduh Tuan Akmal Bin Ramli yang pada 28-11-2018 di wilayah, Songhkla Thailand dituduh berpoligami tanpa diketahui Mahkamah, dengan seorang perempuan bernama Siti Najihah (No. PPT: AR 57124) berlawanan dengan Seksyen 23 Enakmen Undang-Undang Keluarga Islam (Negeri Selangor) 2003. Maka dengan itu, beliau telah melakukan kesalahan di bawah seksyen 124 Enakmen Undang-Undang Keluarga Islam (Negeri Selangor) 2003 dan hendaklah dihukum denda tidak melebihi seribu ringgit atau penjara tidak lebih dari enam bulan atau keduanya. di bawah seksyen dan enakmen yang sama. Ini adalah Kasus kesalahan matrimoni berkaitan dengan berpoligami tanpa kebenaran Mahkamah di bawah seksyen 124 EUUKIS 2003. Tertuduh di laporkan oleh isteri yang pertamanya bahwa tertuduh melaksanakan poligami tanpa sepengetahuan-nya dan pengetahuan isterinya.

Pekara tersebut telah diatur di bawah Seksyen 124 EUUKIS 2003 di bawah tajuk 'Poligami Tanpa Kebenaran Mahkamah': Jika seseorang lelaki menikah lagi di mana-mana saja pun dalam masa perkawinannya yang sedia ada masih berterusan tanpa mendapat kebenaran secara bertulis terlebih dahulu daripada Mahkamah maka dia adalah melakukan suatu kesalahan dan hendaklah dihukum. Perkara tersebut seperti mengabaikan isteri pertama karena berpoligami tanpa pengetahuan nya dan ia akan menjadikan rumah tangga tersebut tidak harmoni dengan sikap rahasia suami kepada isterinya. Sebagaimana firman-Nya dalam Al Quran Surat An Nisa ayat 129:

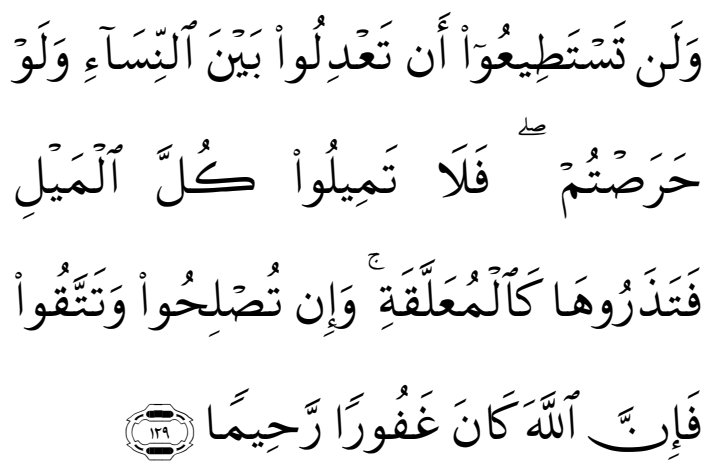

Artinya: Dan kamu tidak akan dapat berlaku adil di antara istri-istri (mu), walaupun kamu sangat ingin berbuat 
demikian, karena itu janganlah kamu terlalu cenderung (kepada yang kamu cintai), sehingga kamu biarkan yang lain terkatung-katung. Dan jika kamu mengadakan perbaikan dan memelihara diri (dari kecurangan), maka sungguh, Allah Maha Pengampun, Maha Penyayang. (Q.S. An-Nisa: 129).

Kasus seperti dapat dilihat bahwa masyarakat Daerah Hulu Langat, Negeri Selangor tidak akan mengenai ketetapan hukum yang telah ditetapkan dan enakmen dari ketetapan hukum tersebut tidak efektif di dalam implimentasi hukumnya.

Meskipun sudah ada peraturan yang telah ditetapkan di setiap negeri bagian, poligami tanpa persetujuan Mahkamah Syariah ini, masih banyak dilakukan karena tidak perlu mengikut prosedur dan takut diketahui istri pertamanya selain tidak mendapat restu orang tua. Poligami tanpa kebenaran Mahkamah juga dilakukan karena kesulitan untuk mendapatkan keizinan istri pertama, dimana tidak semua isteri bersedia untuk dimadu oleh suaminya. Selain itu, kesulitan untuk memohon poligami di Mahkamah juga karena perlu melalui prosedur-prosedur yang ditetapkan terlebih dahulu sebelum diberikan kebenaran daripada Mahkamah Syariah. Kesulitan inilah yang mengakibatkan si suami itu mencari salah satu alternatif lain untuk melanjutkan niatnya adalah dengan cara melakukan poligami tanpa kebenaran mahkamah melalui pernikahan di Luar Negeri dan umumnya menggunakan khidmat juru nikah dari Thailand. Mayoritas yang berpoligami tanpa persetujuan, mereka menikah di luar negeri atau di Thailand Selatan, menggunakan wali hakim sebagai pengganti wali nasab sebagai wali.

Berdasarkan statistik Mahkamah Syariah Negeri Selangor, poligami tanpa kebenaran mahkamah ini menunjukkan peningkatan. Jika dilihat data statistik permohonan atau tuntutan poligami tanpa kebenaran mahkamah di Negeri Selangor dari tahun 2015 hingga 2017 bahawa kasus poligami tanpa kebenaran mahkamah meningkat sebanyak 127 kasus dari 157 kasus pada tahun 2015 kepada 284 kasus pada tahun 2017. Peningkatan terjadi 127 kasus dari 2015 hingga 2017 dan penurunan 4 kasusu sahaja pada tahun 2018. Ini menunjukkan kasus poligami tanpa kebenaran banyak dilakukan dan angka itu boleh dikatakan masih tinggi berbanding di daerah dan negeri-negeri bagian yang lain. 
INTIQAD: JURNAL AGAMA DAN PENDIDIKAN ISLAM

ISSN 1979-9950 (print) || ISSN 2598-0033 (online), http://jurnal.umsu.ac.id/index.php/intiqad

DOI: 10.30596/intiqad.v13i2.8059

Vol. 13, No. 2 (December 2021)

Tabel 1.1.

Statistik Permohonan / Tuntutan Poligami Tanpa Kebenaran Mahkamah Syariah Negeri Selangor.

\begin{tabular}{|c|c|c|c|c|c|}
\hline Tahun & 2015 & 2016 & 2017 & 2018 & Jumlah \\
\hline $\begin{array}{l}\text { Poligmi } \\
\text { Tanpa } \\
\text { Kebenaran } \\
\text { Mahkamah }\end{array}$ & 157 & 162 & 284 & 281 & 884 \\
\hline Sumber: & $\begin{array}{l}\text { Jabatan } \\
\text { Selango } \\
\text { (Portal } \\
\text { Selango }\end{array}$ & $\begin{array}{r}\mathrm{Ke} \\
\text { (JA } \\
\text { Resn } \\
\text { r). }\end{array}$ & (ESS) & $5 \mathrm{Ju}$ & $\begin{array}{l}\text { Negeri } \\
\text { i } 2019 \\
\text { Negeri }\end{array}$ \\
\hline
\end{tabular}

Kasus seperti Poligami Tanpa Izin Mahkamah sudah ada di Malaysia seperti di Daerah Hulu Langat, Negeri Selangor dan boleh dijadikan tempat untuk meneliti kasus ini lebih rinci dan lebih mendalam untuk digunakan sebagai sumber yang boleh kita jadikan sebagai rujukan sumber untuk menjawab persoalan dalam lingkungan bagaimana untuk poligami mengikut ketentuan hukum seterusnya boleh dijadikan sumber pada pengetahuan kita dan pada masyarakat agar semuanya boleh mengetahui akan hal pemasalahan yang melanda ini dan boleh diambil pengajaran dan nilai bahawa poligami itu tidak semudah yang kita sedia sangka.

\section{B. Metode Penelitian}

Penelitian merupakan suatu kegiatan ilmiah, yang didasarkan pada metode, sistematika, dan pemikiran tertentu yang bertujuan mempelajari suatu atau beberapa gejala hukum tertentu dengan jalan menganalisis. Kemudian dalam hal ini penulis menggunakan metode penelitian lapangan (Empiric Reaseacrh) (Dimyati, 2004). Oleh karena itu penelitian ini menggunakan beberapa metode untuk mendapatkan data secara ilmiah, sehingga kebenaran penelitian ini dapat di pertanggung-jawabkan.

\section{Hasil dan Pembahasan}

1. Prosedur Poligami Menurut Undang-Undang No.1 Tahun 1974

Islam adalah agama yang sesuai dengan fitrah manusia dan selalu terjun dalam suatu realitas, mendidik dan menjauhkan diri dari sikap teledor dan bermalas-malasan. Begitulah yang disaksikan dengan jelas dalam hubungannya dengan masalah poligami antara Indonesia dan Malaysia. Walaupun mengikut Undang-Undang No 1 Tahun 1974 dan Enakmen UndangUndang Keluarga Islam (Negeri Selangor) 2003. Dengan menitik beratkan demi kepentingan manusia, baik secara individual maupun masyarakat. Kebanyakan umat dahulu dan agama sebelum Islam membolehkan 
ISSN 1979-9950 (print) || ISSN 2598-0033 (online), http://jurnal.umsu.ac.id/index.php/intiqad

DOI: 10.30596/intiqad.v13i2.8059

Vol. 13, No. 2 (December 2021)

kawin tanpa batas yang kadang-kadang sampai sepuluh wanita, bahkan lebih tanpa suatu syarat ikatan. Dengan datangnya Islam, poligami yang tanpa batas kemudian dibatasi menjadi empat orang istri saja pada waktu yang bersamaan. Poligami ini boleh dilaksanakan dengan persyaratan khusus serta jumlah ketentuan yang harus dilaksanakan. Poligami sendiri memiliki dasar hukum baik dari hukum positif maupun hukum Islam.

\section{Prosedur poligami Undang-} Undang No. 1 Tahun 1974.

Prosedur poligami menurut Pasal 40 Peraturan Pemerintah Nomor 9 Tahun1975 menyebutkan bahwa "apabila seorang suami berkeinginan untuk beristri lebih dari seorang maka ia wajib mengajukan permohonan secara bertulis kepada pengadilan. Hal ini diatur lebih lanjut dalam pasal 56, 57, dan 58 dalam kompilasi Hukum Islam sebagai berikut:

a. Suami yang hendak beristri lebih dari satu orang harus mendapat izin dari Pengadilan Agama.

b. Pengajuan permohonan izin di maksud pada ayat (1) dilakukan menurut tata cara sebagaimana diatur dalam Bab VIII Peraturan

Pemerintah Nomor 9 Tahun 1975

c. Perkawinan yang dilakukan dengan isteri kedua, ketiga atau keempat tanpa izin dari Pengadilan Agama, tidak mempunyai kekuatan hukum.

1) Pasal 57 KHI.

Pengadilan Agama hanya memberikan izin kepada suami yang akan beristri lebih dari seorang apabila :

2) Istri tidak dapat menjalankan kewajiban istri

3) Istri mendapat cacat badan atau penyakit yang tidak dapat disembuhkan

4) Istri tidak dapat melahirkan keturunan.

Kalau pengadilan Agama sudah menerima permohonan izin poligami, kemudian ia memeriksa berdasarkan pasal 57 KHI dengan menggunakan pasal 41 PP No. 9 Tahun 1975 tentang pelaksanaan Undang-Undang No 1 Tahun 1974, yaitu Pasal 41 "Pengadilan kemudian memeriksa mengenai:

1) Ada atau tidaknya alasan yang memungkinkan seorang suami kawin lagi, ialah bahwa istri tidak dapat 
INTIQAD: JURNAL AGAMA DAN PENDIDIKAN ISLAM

ISSN 1979-9950 (print) || ISSN 2598-0033 (online), http://jurnal.umsu.ac.id/index.php/intiqad

DOI: 10.30596/intiqad.v13i2.8059

Vol. 13, No. 2 (December 2021)

menjalankan kewajiban

sebagai istri, bahwa istri

mendapat cacat badan atau

penyakit yang tidak dapat disembuhkan atau bahwa

istri tidak dapat melahirkan

keturunan.

2) Ada atau tidaknya

persetujuan dari istri, baik

persetujuan lisan maupun

tulisan, apabila persetujuan

itu merupakan persetujuan

lisan, persetujuan itu harus

diucapkan di depan siding

Pengadilan.

3) Ada atau tidaknya

kemampuan suami untuk

menjamin keperluan hidup

istri-istri dan anak-anak,

dengan memperlihatkan

surat mengenai penghasilan

suami yang ditandatangani

oleh bendahara tempat

bekerja atau surat keterangan

pajak penghasilan, atau surat

keterangan lain yang dapat

diterima oleh pengadilan

(Saleh, 1976).

Pasal 58 ayat (2) KHI "Dengan

tidak mengurangi pasal 41 huruf

Peraturan Pemerintah Nomor 9 Tahun
1975, persetujuan isteri-isteri dapat diberikan secara tertulis atau dengan lisan, tetapi sekalipun telah ada persetujuan tertulis, pengajuan ini dipertegas dengan persetujuan lisan istri pada sidang Pengadilan"78. Adapun tata cara teknis pemeriksaannya menurut Pasal 42 PP Nomor 9 Tahun 1975 adalah sebagai berikut: Pasal 42

a. Dalam melakukan pemeriksaan mengenai hal-hal pada pasal 40 dan 41, Pengadilan harus memanggil dan mendengar istri yang bersangkutan.

b. Pemeriksaan pengadilan untuk itu dilakukan oleh hakim selambatlambatnya 30 hari setelah di terimanya surat permohonan beserta lampiran-lampirannya.

Apabila terjadi sesuatu dan lain hal, istri-istri tidak mungkin diminta persetujuannya atau tidak dapat menjadi pihak dalam perjanjian, Undang-Undang Nomor 1 Tahun 1974 Pasal 5 ayat 2 menegaskan:

"Persetujuan yang dimaksudkan pada ayat 1 huruf a pasal ini tidak diperlukan bagi seorang suami apabila istri/istri-istrinya tidak mungkin dimintai persetujuannya, dan tidak dapat menjadi pihak dalam perjanjian, atau apabila tidak ada kabar dari istri-istrinya selama sekurang-kurangnya 2 
tahun atau karena sebab-sebab lainnya yang perlu mendapat penilaian ari hakim Pengadilan" (Abdurramab, 1992).

Namun, bila pengadilan berpendapat bahwa cukup alasan bagi pemohon untuk beristri lebih dari seorang, maka pengadilan memberi putusannya yang berupa izin untuk beristri lebih dari seorang. Jadi pada dasarnya pengadilan dapat memberi izin kepada seorang suami untuk beristri lebih dari seorang apabila dikehendaki oleh pihak-pihak yang bersangkutan. Kalau seorang istri tidak mau memberi persetujuan, dan permohonan izin untuk beristri lebih dari satu orang berdasarkan salah satu alasan yang di atur dalam pasal 55 ayat (2) dan Pasal 57, Pengadilan Agama dapat menetapkan pemberian izin setelah memeriksa dan mendengar istri yang bersangkutan di persidangan Pengadilan Agama, dan terhadap penetapan ini istri atau suami dapat mengajukan banding atau kasasi. Apabila keputusan hakim yang mempunyai kekuatan hokum tetap, izin pengadilan tidak diperoleh, maka menurut ketentuan Pasal 44 PP Nomor 9 Tahun 1975, Pegawai Pencatat dilarang untuk melakukan pencatatan perkawinan seorang suami yang akan beristri lebih dari seorang sebelum adanya izin pengadilan seperti yang dimaksudkan dalam Pasal 43 PP Nomor 9 Tahun 197583 .

Ketentuan hokum yang mengatur tentang pelaksanaan poligami seperti telah diuraikan di atas mengikat semua pihak, pihak yang akan melangsungkan poligami dan pegawai pencatat perkawinan. Apabila mereka melakukan pelanggaran terhadap ketentuan pasalpasal di atas dikenakan sanksi pidana. Persoalan ini diaturkan dalam Bab IX pasal 45 PP Nomor 9 Tahun 1975:

Kecuali apabila ketentuan lain dalam peraturan perundangan-perundangan yang berlaku, maka:

a. Barang siapa melanggar ketentuan yang diatur dalam pasal 3, pasal 10 ayat (3), 40 Peraturan Pemerintah akan dihukum dengan hokum denda setinggi-tingginya Rp. $7.500,00$.

b. Pegawai Pencatat yang melanggar ketentuan yang diatur dalam pasal $6,7,8,9,10$ ayat $(1), 11,12$, dan 44 Peraturan Pemerintah ini dihukum dengan hukuman kurungan selama-lamanya 3 Bulan atau denda setinggi-tingginya $\mathrm{Rp}$. $7.500,00$. 
c. Tindak Pidana yang dimaksudkan dalam ayat (1) di atas merupakan pelanggaran.

Ketentuan hukum poligami yang boleh dilakukan atas kehendak yang bersangkutan melalui Pengadilan Agama, setelah dibuktikan kemaslahatan nya. Dengan kemaslahatan dimaksud, terwujudnya cita-cita dan tujuan perkawinan itu sendiri, yaitu rumah tangga yang kekal dan abadi atas dasar cinta dan kasih sayang yang diridhai Allah SWT. Oleh karena itu, segala persoalan yang dimungkinkan akan menjadi penghalang bagi terwujudnya tujuan perkawinan tersebut, sehingga mesti dihilangkan atau setidaknya dikurangi (Abdurramab, 1992).

\section{Seksyen 23 Bahagian 2 Enakmen Undang Undang Hukum Keluarga Islam (Negeri Selangor) Tahun 2003.}

Sebelum membahas tentang prosedur poligami di Negeri Selangor 2003, ada baiknya lebih dahulu menguraikan secara ringkas analisis tentang prosedur poligami yang diatur dalam Enakmen Undang-Undang Keluarga Islam (Negeri Selangor) 2003. Secara yuridis normatif yang berlaku di
Malaysia, laki-laki dibenarkan menikahi dengan dua wanita atau lebih. Namun, bukan dalam arti kata bebas melakukannya dan dimana saja tanpa mengikuti jalur formalitas. Suami boleh berpoligami tetapi harus mengikut prosedur yang berlaku di dalam perundangan-perundangan yang ada.

Berikut merupakan Seksyen yang berkaitan dengan Poligami yang diatur di Enakmen Undang Undang Keluarga Islam (Negeri Selangor) Tahun 2003:
a. Seksyen 23 Bahagian 2 - Poligami
b. Seksyen 124 Bahagian 9 - Poligami tanpa kebenaran mahkamah
c. Seksyen 16 Bagian 2 - Pemohonan untuk kebenaran berkawin.

d. Seksyen 17 Bahagian 2 Mengeluarkan kebenaran berkahwin.

Seksyen di atas adalah merupakan seksyen yang terkait dengan pelaksanaan poligami yang ditetapkan oleh (EUUKIS 2003), di mana pada Seksyen 23 (EUUKIS 2003) telah menetapkan tentang tatacara dan ketentuan berpoligami yaitu: (Warta Kerajaan, 2003).

1) Tiada seorang pun lelaki semasa wujudnya suatu perkawinan boleh, 
INTIQAD: JURNAL AGAMA DAN PENDIDIKAN ISLAM

ISSN 1979-9950 (print) || ISSN 2598-0033 (online), http://jurnal.umsu.ac.id/index.php/intiqad

DOI: 10.30596/intiqad.v13i2.8059

Vol. 13, No. 2 (December 2021)

kecuali dengan mendapat

kebenaran terlebih dahulu secara

bertulis daripada Mahkamah,

membuat akad nikah perkawinan

yang lain dengan perempuan lain.

2) Tiada perkawinan yang

diakadnikahkan tanpa kebenaran di

bawah subseksyen (1) boleh

didaftarkan di bawah Enakmen ini

melainkan jika Mahkamah

berpuashati bahawa perkawinan

sedemikian adalah sah mengikut

Hukum Syarak dan Mahkamah

telah memerintah supaya

perkawinan itu didaftarkan

tertakluk kepada seksyen 124.

3) Subseksyen (1) terpakai bagi perkawinan dalam Negeri Selangor seseorang lelaki yang bermastautin dalam atau di luar Negeri Selangor dan perkawinan di luar Negeri Selangor seseorang lelaki yang bermastautin dalam Negeri Selangor.

4) Permohonan untuk kebenaran hendaklah dikemukakan kepada Mahkamah mengikut cara yang ditetapkan dan hendaklah disertai dengan suatu iqrar menyatakan alasan-alasan mengapa perkawinan yang dicadangkan itu dikatakan patut atau perlu, pendapatan pemohon pada masa itu, butir-butir komitmennya dan kewajipan tanggungan kewangannya yang patut ditentukan, bilangan orang tanggungannya, termasuk orang yang akan menjadi orang tanggungannya berikutan dengan perkawinan yang dicadangkan itu, dan sama ada izin atau pandangan isteri atau isteri-isterinya yang sedia ada telah diperolehi atau tidak terhadap perkawinannya yang dicadangkan itu.

5) Apabila menerima permohonan itu, Mahkamah hendaklah memanggil pemohon, isteri atau isteri-isterinya yang sedia ada, bakal isteri, wali kepada bakal isteri, dan mana-mana orang lain yang difikirkan oleh Mahkamah boleh memberi keterangan mengenai perkawinan yang dicadangkan itu supaya hadir apabila permohonan itu didengar, yang hendaklah dilakukan dalam Mahkamah tertutup, dan Mahkamah boleh memberi kebenaran yang dipohon itu jika berpuas hati (warta Kerajaan, 2003). 
a) Bahwa perkawinan yang dicadangkan itu adalah patut atau perlu, memandang kepada, antara lain, hal-hal keadaan yang berikut, iaitu, kemandulan, keuzuran jasmani, tidak layak dari segi jasmani untuk persetubuhan, sengaja ingkar mematuhi perintah untuk pemulihan hak-hak persetubuhan, atau gila di pihak isteri atau isteri-isteri yang sedia ada.

b) Bahwa pemohon mempunyai kemampuan yang

membolehkan dia menanggung, sebagaimana dikehendaki oleh Hukum Syarak, semua isteri dan orang tanggungannya, termasuk orang yang akan menjadi orang-orang tanggungannya berikutan dengan perkawinan yang dicadangkan itu;

c) Bahwa pemohon akan berupaya memberi layanan adil kepada semua isterinya mengikut kehendak Hukum Syarak; dan

d) Bahwa perkawinan yang dicadangkan tidak akan menyebabkan dasar syar'i kepada isteri atau isteri-isteri yang sedia ada.

e) Satu salinan permohonan di bawah subseksyen (4) dan iqrar yang dikehendaki oleh subseksyen itu hendaklah disampaikan bersama dengan surat panggilan ke atas tiap-tiap isteri yang sedia ada.

f) Mana-mana pihak yang terkilan atau tidak puas hati dengan apaapa keputusan Mahkamah boleh merayu terhadap keputusan itu mengikut cara yang diperuntukkan di bawah Enakmen Tatacara Mal (Negeri Selangor) [Enakmen 4/2003] 2003.

g) Mana-mana orang yang membuat akad nikah bersalahan dengan sub-seksyen hendaklah membayar dengan serta merta semua jumlah mas kahwin dan pemberian yang kena dibayar kepada isteri atau isteri-isteri yang sedia ada, dan jika jumlah itu tidak dibayar sedemikian, boleh dituntut sebagai hutang (ibid).

h) Acara bagi akad nikah dan pendaftaran sesuatu perkawinan 
INTIQAD: JURNAL AGAMA DAN PENDIDIKAN ISLAM

ISSN 1979-9950 (print) || ISSN 2598-0033 (online), http://jurnal.umsu.ac.id/index.php/intiqad

DOI: 10.30596/intiqad.v13i2.8059

Vol. 13, No. 2 (December 2021)

di bawah seksyen ini adalah serupa dalam serba perkara dengan yang dipakai bagi perkawinan-perkawinan lain yang diakad-nikahkan dan didaftarkan dalam Negeri Selangor di bawah Enakmen ini.

i) Tiap-tiap Mahkamah yang memberi kebenaran atau memerintahkan supaya perkawinan itu didaftarkan di bawah seksyen ini, hendaklah mempunyai kuasa atas permohonan mana-mana pihak kepada perkawinan:

(a) Untuk menghendaki seseorang untuk membuat pembayaran nafkah kepada isteri atau isteriisteri yang sedia ada; atau

(b) Untuk memerintahkan supaya apa-apa aset yang telah diperoleh oleh pihak-pihak itu dalam masa perkawinan dengan usaha bersama mereka dibagi antara mereka atau supaya mana-mana aset itu dijual dan hasil jualan itu dibagikan.
Selain itu, Seksyen 124 bagian 9 (EUUKIS) 2003 adalah merupakan ketetapan sanksi Poligami tanpa kebenaran mahkamah yang telah ditetapkan yaitu "Jika seseorang lelaki menikah lagi di mana-mana jua pun dalam masa perkawinannya yang sedia ada masih berlangsung tanpa mendapat persetujuan secara bertulis terlebih dahulu daripada Mahkamah maka dia adalah melakukan suatu kesalahan dan hendaklah dihukum denda tidak melebihi satu ribu ringgit atau penjara tidak melebihi enam bulan atau keduaduanya denda dan penjara itu." Pihak yang melaksanakan poligami tanpa izin boleh memohon rayuan agar sanksi tersebut dikurangkan melalui seksyen 123 yaitu "Mana-mana orang yang terkilan dengan mana-mana keputusan mana-mana Mahkamah, atau mana-mana Pendaftar di bawah Enakmen ini boleh merayu kepada Mahkamah Rayuan Syariah”(Warta Kerajaan).

\section{Faktor Masyarakat Daerah Hulu Langat melaksanakan poligami tanpa kebenaran Mahkamah.}

Dalam Undang-Undang keluarga Islam di Selangor, poligami diizinkan 
dengan syarat suami mesti mendapat izin tertulis daripada Mahkamah Syari'ah terlebih dahulu. Ini diperuntukkan dalam seksyen 22 (1) Enakmen UndangUndang Keluarga Islam Selangor 2003. Menurut seksyen 23(2) EUKIS 2003, permohonan suami hendaklah dikemukakan kepada Mahkamah mengikut tatacara yang ditetapkan dan hendaklah disertai dengan suatu ikrar. Ikrar tersebut harus memuat alasanalasan mengapa pernikahan poligami ini patut dan perlu, keadaan keuangan suami dengan memberi butir-butir komitmennya dan tanggungan keuangannya yang patut ditentukan serta bilangan tanggungan termasuk orang yang akan ditanggungnya berikutan dengan pernikahan baru yang dicadangkan. Selain itu istri atau istriistrinya boleh dipanggil oleh pihak Mahkamah supaya permohonan itu dapat didengar. Mahkamah dalam memberi pertimbangan akan memperhatikan empat syarat sebelum diizinkan untuk berpoligami sebagaimana yang diperuntukkan dalam seksyen 23(5) EUKIS 2003, yaitu:
a. Bahwa pernikahan yang dicadangkan itu adalah patut atau perlu, memandang kepada, antara

lain, hal-hal keadaan yang berikut, iaitu, kemandulan, keuzuran jasmani, tidak layak dari segi jasmani untuk persetubuhan, atau gila di pihak istri atau istri-istri yang sedia ada.

b. Bahwa pemohon mempunyai kemampuan yang membolehkan dia menanggung, sebagaimana dikehendaki Hukum Syara', semua istri dan orang tanggungannya, termasuk orang yang akan menjadi orang-orang tanggungannya berikutan dengan pernikahan yang dicadangkan itu.

c. Bahwa pemohon akan berupaya memberi layanan adil kepada semua isterinya mengikut kehendak Hukum Syara.

d. Bahwa pernikahan yang dicadangkan tidak akan menyebabkan darar syarie kepada istri atau istri-istri yang sedia ada.

Sebagaimana yang telah dijelaskan di atas bahwa Enakmen Undang-Undang Keluarga Islam Selangor (EUKIS 2003) telah menetapkan dengan jelas tentang kesalahan berpoligami tanpa izin Mahkamah. Akan tetapi amalan ini masih terus berlaku walaupun undangundang dengan tegas melarang perkara 
ISSN 1979-9950 (print) || ISSN 2598-0033 (online), http://jurnal.umsu.ac.id/index.php/intiqad

DOI: 10.30596/intiqad.v13i2.8059

Vol. 13, No. 2 (December 2021)

tersebut. Kasus ini dikira sebagai kasus jinayah dalam bidangkuasa Mahkamah Tinggi Syari’ah.

Berdasarkan hasil wawancara penulis dengan Penolong Pendaftar bagi Pihak Hakim Mahkamah Rendah Syari'ah Hulu Langat yaitu Nor Liana Binti Zainon dan beberapa masyarakat di daerah tersebut dapat disimpulkan bahwa banyaknya kasus poligami tanpa izin dikalangan masyarakat Islam di daerah Hulu Langat, Selangor adalah disebabkan beberapa faktor utama yaitu:

1) Faktor Undang-undang

2) Faktor Pasangan

3) Faktor Geografis

4) Faktor Sosial

Syarat dan proses undang-undang yang terlalu ketat menjadi faktor utama bagi kaum lelaki yang tidak memenuhi kriteria yang ditetapkan dalam EUKIS 2003 untuk melakukan poligami tanpa izin Mahkamah. Mereka mengambil jalan mudah dengan membelakangkan undang-undang karena mengetahui adalah mustahil bagi mereka untuk berpoligami sekiranya mengikut jalur hukum.

Dengan berpoligami tanpa izin ini juga dapat menghemat waktu dan biaya yang terbuang daripada proses permohonan poligami yang belum tentu akan diluluskan oleh Mahkamah karena izin bagi laki-laki untuk melakukan poligami sangat kondisional, tidak absolut dan karenanya sangat dibatasi dengan peraturan, perjanjian atau hukum.

a) Faktor Undang-undang.

Undang-undang mengenakan sanksi berupa denda tidak melebihi RM1000 bagi pelaku poligami tanpa izin. Sanksi ini dianggap masih relatif murah dan tidak membebankan bagi masyarakat Islam di Hulu Langat membuatkan ketentuan hukum ini tidak terlalu ditanggapi. Ini karena jumlah denda tersebut masih ringan dan terjangkau memandangkan kedudukan sosio ekonomi masyarakat di sini yang berada di kawasan kota dan rata-ratanya berpendapatan tetap. Ini dapat dilihat dalam senarai kasus yang mana para pelaku poligami tanpa izin ini terdiri dari pelbagai lapisan masyarakat, seperti pegawai kerajaan (PNS) dari peringkat bawahan hingga yang yang berpangkat besar, wiraswasta, pengusaha dan sebagainya.

b) Faktor Pasangan

Kebanyakan pasangan yang berpoligami tanpa izin ini biasanya 
adalah atas dasar cinta. Perasaan cinta dan kasih sayang yang menggebu diantara laki-laki dan pasangannya tersebut membuatkan dia nekad untuk berpoligami walaupun dia tidak berkemampuan dari segi lahir dan batin. Sang kekasih pun rela untuk dimadukan walau dengan apa cara sekalipun menguatkan lagi semangat pasangannya untuk melakukan praktik poligami tanpa izin.

c) Faktor Geografis

Hampir keseluruhan pasangan yang melakukan praktek poligami tanpa izin bernikah diluar negeri. Ini karena tidak akan ada pihak yang mau menganjurkan upacara pernikahan tanpa kehadiran pegawai pencatat nikah di Malaysia karena ia adalah suatu kesalahan jenayah menurut EUKIS 2003.

Oleh karena kedudukan geografis negeri Selangor yang terletak di timur Malaysia berkedudukan di antara Malaysia dan Selatan Thailand, maka amat mudah bagi para suami yang ingin berpoligami untuk pergi ke sana dan melakukan praktek poligami ini dengan mendapatkan khidmat juru nikah dari negara tetangga tersebut tanpa memerlukan izin dari mahkamah. Ini menyebabkan lokasi ini menjadi destinasi populer bagi pasangan yang ingin berpoligami secara rahasia. Ini diburukkan lagi dengan terdapat beberapa sindikat yang mengaut keuntungan dengan menganjurkan pernikahan secara illegal di negara berkenaan.

\section{d) Faktor Sosial}

Rata-rata masyarakat Islam di Selangor dan di Hulu Langat khususnya masih berpegang kuat pada ajaran agama Islam. Ini terbukti dengan terdapat banyaknya sekolah-sekolah madrasah dan pondok-pondok pesantren yang masih beroperasi di Selangor. Dalam kondisi masyarakat yang kuat pegangan agamanya, masyarakat Islam Selangor menolak kemungkaran dan kemaksiatan.

Oleh karena itu banyak kaum lelaki lebih memilih untuk melakukan poligami walaupun dengan tanpa izin Mahkamah untuk mengelak daripada perbuatan maksiat dan perzinahan yang konsekuensinya kan berakibat buruk kepada masyarakat.

Walaupun pandangan ini ada benarnya dari satu sisi tetapi disisi yang lainnya ia akan mengundang masalah yang lebih besar kepada kesejahteraan rumahtangga karena bersalahan dengan 
INTIQAD: JURNAL AGAMA DAN PENDIDIKAN ISLAM

ISSN 1979-9950 (print) || ISSN 2598-0033 (online), http://jurnal.umsu.ac.id/index.php/intiqad

DOI: 10.30596/intiqad.v13i2.8059

Vol. 13, No. 2 (December 2021)

undang-undang yang ditetapkan pemerintah.Berdasarkan tabel dan pernyataan di atas, maka penulis berpendapat bahwa sanksi hukum yang ada sekarang ini adalah kurang efektif dari segi keberadaan dan peruntukan undang-undang dalam mencegah berlakunya praktek poligami tanpa izin di daerah Hulu Langat karena ia tidak memiliki kekuatan dan daya pengikat untuk dipatuhi oleh masyarakat. Ini dapat dilihat dari keberlangsungan praktek ini yang terus berlanjut dalam jumlah yang tidak sedikit walaupun sudah berkali-kali tahun undang-undang ini diubah.

Setelah meneliti dan menganalisa data-data penelitian ini, maka di sini penulis paparkan beberapa timbangan pemikiran yang penulis temukan dari inti pembahasan

ini.Secara konsepnya penulis mendapati bahwa keberadaan Enakmen Undang-

Undang Keluarga Islam Selangor 2003 adalah untuk menjaga maslahah umat Islam di Negeri Selangor. Sebagaimana yang telah diketahui bahwa Enakmen UndangUndang Keluarga Islam Selangor 2003 sangat ketat dalam meletakkan syarat bagi membolehkan seorang suami untuk berpoligami. Sungguhpun dari satu sisi, hukum yang ketat ini menampakkan dampak yang positif, namun di satu sisi yang lainnya hukum yang ketat ini memberikan dampak negatifnya yaitu para suami yang ingin berpoligami tetapi tidak memenuhi syarat yang ditetapkan memilih membelakangkan hukum dengan melakukan praktek poligami secara illegal ataupun tanpa izin dari mahkamah.

Seterusnya, berdasarkan hasil wawancara penulis bersama beberapa masyarakat di daerah Hulu Langat yang melakukan poligami tanpa kebenaran mahkamah ini disebabkan beberapa faktor dan alasan mereka tersendiri.

\section{Kesimpulan}

Uraian yang telah penulis paparkan seacara panjang lebar pada setiap bab sebelumnya. Maka sebagai ahkhir daripada bahagian penelitian ini penulis akan menarik kesimpulan untuk menjawab permasalahan yang penulis dan penulis mengambil kesimpulan sebagai berikut.

1. Poligami di Mahkamah Syariah Hulu Langat mengikut panduan dalam konteks perundangan Islam 
INTIQAD: JURNAL AGAMA DAN PENDIDIKAN ISLAM

ISSN 1979-9950 (print) || ISSN 2598-0033 (online), http://jurnal.umsu.ac.id/index.php/intiqad

DOI: 10.30596/intiqad.v13i2.8059

Vol. 13, No. 2 (December 2021)

di Malaysia, perkara yang berhubung dengan poligami mestilah dilihat dalam Enakmen Undang undang Keluarga Islam di Negeri Negeri. Sekalipun Islam membenarkan poligami namun setiap laki laki Islam yang ingin berpoligami di Malaysia haruslah tertakluk kepada Enakmen yang telah ditetapkan oleh Mahkammah Rendah Syariah Hulu Langat. Syarat-syarat yang dinyatakan di bawah Seksyen 23 bahagian 2 adalah bagi memastikan istri istri mendapat keadilan supaya hak mereka terpelihara dan dilindungi. Adapaun syarat syarat yang harus dipenuhi, pertama poligami tanpa izin terlebih dahulu dari pengadilan tidak boleh didaftarkan, Kedua Poligami tanpa izin lebih dahulu dari pengadilan boleh didaftarkan dengan syarat harus memabayar denda atau menjalani hukuman yang telah ditentukan.

2. Sistem poligami tidak akan digunakan kecuali dalam kondisi mendesak saja. Tujuan mengapa harus disyariatkan poligami adalah agar tidak ada satupun perempuan muslimah dimanapun mereka berada hidup dalam sebuah masyarakat tanpa memiliki suami. Semuanya bertujuan agar lingkungan tersebut terbebas dari kesesatan ketika mereka mendapat posisi sebagai isteri kedua tidak akan melakukan hal yang menyimpang. Sekalipun, ia tidak mendapatkan kesempatan untuk menjadi isteri yang pertama. Perempuan tersebut benar-benar telah menggunakan kesempatan emas yang terpampang di hadapannya dan sepertinya ia berpendapat bahwa menjadi isteri yang kedua lebih baik daripada tidak menikah sama sekali. Oleh sebab itulah sehingga seharusnya seseorang yang ingin melangsungkan poligami maka ia harus memahami segalah hak dan kewajibannya sebagai suami dan isteri, baik itu hak-hak anak maupun hak-hak para isteriisterinya, agar tidak

3. Faktor berlakunya Poligami di Malaysia ialah karena alasannya isteri uzur, isteri mandul, mahu menambah anak, menolong isteri baru (dari agama lain dan miskin), suami lebih bertenaga, tanpa sebab 
INTIQAD: JURNAL AGAMA DAN PENDIDIKAN ISLAM

ISSN 1979-9950 (print) || ISSN 2598-0033 (online), http://jurnal.umsu.ac.id/index.php/intiqad

DOI: 10.30596/intiqad.v13i2.8059

Vol. 13, No. 2 (December 2021)

yang munasabah, telah mengandung (zina), berjauhan (bekerja), rujuk isteri lama, desakan ibu, ingin menikah satu lagi (cinta, berkenalan lama, jiwa tertekan dan kosong, berjanji dengan bakal isteri, isteri suruh), menambah zuriat (laki-laki dan perempuan), berpendapatan lebih, nafsu terlalu kuat, mengelak dari melakukan perkara- perkara mungkar, kasihan, khalwat dan alasan agama yaitu Islam membenarkan serta untuk memantapkan rumahtangga. Kadang-kadang, isteri pertama hanya menjadi mangsa dan ada yang diugut serta dipaksa untuk menerima poligami.Walaupun keijinan isteri adalah faktor yang perlu dipertimbangkan oleh Mahkamah Syariah dalam memberi kebenaran berpoligami, ia sebenarnya bukan keperluan wajib. Dalam realiti, isteri hanya diminta menandatangani borang permohonan saja.

\section{E. Daftar Pustaka}

Abdurramab. (1992). Kompilasi Hukum Islam di Indonesia. Jakarta: Akademik Pressindo.

Ahmad, Muhammad Ali Al Nadwi (2000). Al Qawaid Al Fiqhiyyah, Damsyiq: Dar al-Qalam.

Amin, Suma Muhammad. (2008) Undang Undang Perdata Islam dan Peraturan Pelaksanaan Lainnya di Negara Hukum Indonesia. Jakarta: Rajawali Pers,.

Dimyati, Khudzaifah dan Kelik Wardiyono. (2004). Metode Penelitian dan Penulisan Hukum. Surakarta: Fakultas Hukum UMS.

Doi, Abdurrahman I. (1996). Karakteristik Hukum Islam dan

Perkawinan. Jakarta: Raja Grafindo Persada

Doi, Abdurrahman I. (1992). Perkawinan dalam Syari"at Islam", Syariee at The Islamic Law, Terj. Basri ba Asghary, Wadi Masturi, Jakarta: Rineka Cipta.

Enakmen Tahun 2003. (2003). Enakmen Undang Undang Keluarga Islam, (Negeri Selangor)

Al Gazali, Muhammad (tt). Fiqh Sirah Menghayati Nilai-nilai RIwayat Hidup Rasullah SAW, terj. Abu 
INTIQAD: JURNAL AGAMA DAN PENDIDIKAN ISLAM

ISSN 1979-9950 (print) || ISSN 2598-0033 (online), http://jurnal.umsu.ac.id/index.php/intiqad DOI: 10.30596/intiqad.v13i2.8059

Vol. 13, No. 2 (December 2021)

Laila dan Muhammad Thorir.

Surabaya: Terbitan Ampel

Bandung: Al Ma'rifat.

Surabaya.

Ghazaly, Abd Rahman. (2003). Fiqh

Munakahat. Bogor: Kencana.

Tihami, Sohari Sahran. (2014). Fikih

Munakahat. Jakarta: PT.

al-Habsyi, Muhammad Bagir. (tt). Fiqih

RajaGrafindo Persada.

Praktis Menurut Al-Qur"an, as-

Undang-Undang (2007) Pokok

Sunah, dan Pendapat Para Ulama.

Perkawinan Nomor 1 tahun 1974.

Bandung: Mizan Media Utama.

Izzat, Abu. (2004). Fiqh Keluarga

Islam. Kuala lumpur: cetakan Al-

Hidayah.

Jakarta: Sinar Grafika.

Warta Kerajaan. (2003) Government Of

Selangor Gazette Published by

Authority. Selangor.

Rofiq, Ahmad. (2000). Hukum Islam di

Indonesia. Jakarta: Raja Grafindo Persada.

Al-Yasin, Jaism Muhammad. (2017)

Fiqh Wanita, Cet, Jakarta: PT

Serambi Semesta Distribusi.

Saleh, K. Wantik. (1976) Hukum

Perkawinan Indonesia. Jakarta:

Ichtiar Baru

Sunarto, Achmad. (2014). Dibalik

Sejarah Poligami Rasulullah 